\title{
COMPARATIVE HERMENEUTICS, SOCIAL ACTION, AND METANARRATIVES: A RESPONSE
}

\author{
Gerhard van den Heever \\ Department of Biblical and Ancient Studies \\ UNISA
}

\begin{abstract}
This essay responds to the three main position papers of the 2018 CIAS workshop, which were published in Religion \& Theology 26, no. 1 \&2 (2019). The main thrust of the essay relates to the concept of hermeneutics and the location of the discourse of comparative hermeneutics. The essay defines the fundamental question at stake as a question of discourse. From this basis, the paper proceeds to consider four main issues that constitute the framework for conceiving a Centre for the Interpretation of Authoritative Scripture: to wit, historicising of scripture and tradition, the character of texts and textual traditions and canons, comparative religion and hermeneutics as discourse and the implied definition of religion (and of religion as social discourse). Firstly, comparative hermeneutics raises the problem of what a tradition is. What constitutes its essential identity? Secondly, it is possible, and this essay explores this line, to redescribe hermeneutics as a social discourse, that is, to understand interpretation as social interaction. It is when the concept of religion is historicised, and the complex and contestatious processes of social and identity-formation are investigated, that the social discursivity, authority construction and power-effects, and the ideological work performed by tradition-formation can be brought to light. In this manner, the essay argues for the de-essentialisation of religious traditions such that it is possible to think beyond narrowly delimited boundaries and rather see the common human activity of social discourse productions that bind adherents of different religious traditions in a given social aggregation together - which enables thinking common social purposes.
\end{abstract}

Keywords: Comparative hermeneutics; Historicisation; Scriptural reasoning; Interreligious dialogue; Discourse; Study of religion

\section{Introduction}

This essay responds to the three main papers read at the inaugural consultation workshop to investigate the possibility of establishing a Centre for the Interpretation of Authoritative Scriptures (CIAS), held on 13 to 14 September 2018 at Stellenbosch University. ${ }^{1}$ The three papers were subsequently published in Religion \& Theology 26,

1 This response was presented as a main paper at the subsequent workshop for the Centre for the Interpretation of Authoritative Scriptures (CIAS), held on 11 to 13 September 2019 at Stellenbosch University. Due to restrictions regarding length, this essay is a severely curtailed version of what was presented originally - in effect, this is only an extract of a longer argument. 
no. 1\&2 (2019): Louis Jonker, "Establishing a Centre for the Interpretation of Authoritative Scriptures (CIAS). Why Focus on Hermeneutics?" (Jonker 2019); Jeremy Punt, "What Are Authoritative Scriptures?" (Punt 2019); and Marius J. Nel, "The Relationship Between Christian Metanarratives and Authoritative Scriptures in South African Society" (Nel 2019).

Jonker sets up the discussion on the project by emphasising that the project on comparative hermeneutics focuses on the impact that scriptural interpretation in the three main religious traditions in South Africa, viz. Christianity, Islam, and Judaism, made not only on the formation of the three traditions internally (being appealed to as the foundation for the rituals and customs of these religious communities), but also on the cultural and social existence of these communities (the worldviews, beliefs, ethical values, ideological positions, and generally, political discourses in South African society). It is especially in the latter domain that these religious traditions have become imbricated in popular consciousness in matters relating to social cohesion or social conflict (Jonker 2019:41-42). ${ }^{2}$ Given the role that sacred scriptures play in social and cultural formation of traditions that stand in conflictual relation to each other, the issue of the interpretation of scriptures is of paramount importance to investigate (Jonker 2019:43-45). For this purpose, interreligious hermeneutics is mooted as an approach to achieve the desired insight into how authoritative scriptures can be studied to achieve social cohesion. In this respect, an appeal is made to Cornille and Conway (2010) to help set the terms for interreligious hermeneutics; as Cornille and Conway put it: it entails a) "the hermeneutical retrieval of resources for dialogue within one's own tradition"; b) "the pursuit of proper understanding of the other"; c) "the appropriation and reinterpretation of the other within one's own religious framework"; and d) "the borrowing of hermeneutical principles of another religion" (Cornille and Conway 2010:x). For the purposes of the intended Centre, this is then appropriated and complemented with an historical approach that pays attention to the origins of scriptures and the way in which they became authoritative, histories of interpretation and re-interpretation, functioning hermeneutical traditions, the role of these hermeneutical traditions in South Africa, and the possibility of bringing diverse hermeneutical traditions into dialogue and mutual discourse (Jonker 2019:47).

Punt extends the argument put forward by Jonker by promoting a way of understanding Scripture as concept, as authoritative or canonical scriptures, as cypher or as stand-in for certain kinds of social relationships that are encoded in such scriptures. It is relations of power that manifest in claims to authority, first in the production of such writings, then in the vesting of authority in them, and finally in the authoritative interpretation of such scriptures. Once vested with authority, scriptures function as symbols that authorise whatever viewpoint is put forward in the contestatious process

These kinds of conflictual discourses manifested acutely in the wake of public reaction to events like 9/11 and its aftermath in the "War on Terror" and the ongoing military conflicts in the Near East; the spectacle of violence by ISIS members in Iraq and Syria; terror attacks in Europe, for instance, the Charlie Hebdo killings in Paris; the discourse on the banning of the burqa in Europe; and the general fear of Europe turning into "Eurabia" (all of these are topics that featured regularly in conversations and public opinion on Islam in South Africa); but also from the side of Muslim South Africans regarding the oppression of Palestinians in Israel. 
that is the definition of religious identity, merely by representing a point of reference. Hence the recurring questions: Whose Scripture? Whose authority? "Power, ownership and proxy: whose Scriptures are they anyway?" (Punt 2019:58). And so the scriptural tradition, as well as the use- or interpretation of traditions, becomes a flashpoint where contests regarding the right to define the content and substance of religious truth and identity play out. Punt thus theorises Christian Scriptures as social interventions, as the site for authority construction, and asks what the word "authoritative" means with respect the Christian Bible, with a view to the social function of such Scriptures, particularly how such authoritative power impacts on gender issues as a very contemporary case in point.

Finally, Nel links up with the foregoing essays in that he takes the wider contemporary perspective on how different authoritative Scriptures of Judaism, Christianity, and Islam function as a foundation for metanarratives as the overarching view of universal history (in their function as explanations for the suchness of creation and the history of humankind), as well as the history of each respective religious tradition - authoritative metanarratives thus help to "stabilise" tradition in that they suppress dissent and create (at least officially) conformity to the grand tradition, hence the presence of heresiological discourses in each of these three traditions. And in turn, these metanarratives sanction the authority of their scriptures (Nel 2019:73-74). Hence, Nel advocates that the "propensity of metanarratives to legitimise their power, authority, and values, and the ease with which metanarratives can be manipulated, and with which they mutate, necessitate that the three monotheistic religions that relate their metanarratives to authoritative Scriptures critically evaluate this relationship at all times" (Nel 2019:74). The particular focus announced in the essay as a preliminary exploration is that of the "relationship between the Christian metanarrative and the authoritative texts of the New Testament canon" and the mutually constitutive relation between a Christian metanarrative and the production of a canon of Scripture (Nel 2019:78-81).

A number of themes run as interwoven golden threads through these essays: historicising of scripture and tradition, the character of texts and textual traditions and canons, comparative religion and hermeneutics as discourse, and the implied definition of religion (and of religion as social discourse). None of these themes stand alone in themselves but are rather part of a mutually implicating and mutually defining set of theoretical perspectives, and it is the aim of this essay to argue precisely for such an integrated theoretical frame. Thus, it follows that pursuant to the desired outcomes of the research project - for this is a research project seed-funded in the first instance by the National Research Foundation (NRF) (and is not directly and in the first instance a community project) - a redescriptive theoretical framework is essential to steer the research project such that, precisely because it is located in an academic institution of higher learning, it does not merely encompass descriptive instantiations of religious projects viewed from the inside of committed localisations in religious communities (as such, given its nature and focus, this project also raises the question of who owns the discourse and what the purpose is of scholarship). As will be argued below, the questions raised by the formulation of the focus of the research project towards the establishment of the Centre are questions that drill right into the core of how religion and 
hermeneutics are theorised and how the purpose of research and scholarship is conceived.

\section{The ownership of the research programme and its historical character}

There are two important matters to reflect on here. They are: the ownership of the research programme and the historical character of the research project. Since both Jonker and Punt emphasised history and historical processes as guiding principles and the arena for investigating the uses of and interpretation of scriptures with a view to understanding how scriptural discourses shape social interaction, it is worth focusing attention on the concept of historicisation. To historicise, in short, means to situate the phenomenon investigated squarely within the domain of human agency and action. ${ }^{3}$ With respect to culture and religion, scholars speak in this regard of historicising tradition, that is, to show how tradition is constantly manufactured and remade by human agents (e.g., Engler and Grieve 2005; Grieve and Weiss 2005; Lewis and Hammer 2007). Historicising the study of religious traditions and religious social formations will obviously have an important bearing on the kind of investigation this project is concerned with and therefore informs the next point.

Having raised the issue of the "ownership" of the research project, another important introductory question which needs to be asked - and answered - is this: to whom belong the discourse and the research programme? Apart from the fact that it is seed-funded by the NRF, which in itself brings with it certain requirements and constraints bearing on the research project (such as standards of research, methodological conventions, theoretical justification, etc.), the kinds of presentations made at the inaugural workshop seemed to suggest that there was an expectation of an immediate relevance and applicability to the intended study to be hosted in the Centre. This is not surprising as mention was made more than once of scriptural reasoning as method in such a comparative hermeneutic.

\section{Scriptural reasoning as method of inter-religious dialogue}

Scriptural reasoning is a particular form of inter-religious dialogue in which "Jews, Christians, and Muslims temporarily suspend their sibling rivalries to become guests in one another's rich scriptural traditions" (Moyaert 2013:64). It is intended to promote a practice of inter-religious dialogue through textual readings (in-depth engagement with sacred texts) to contribute to reconciliation between people of different religious persuasions (in particular, between Christians, Jews, and Muslims). ${ }^{4}$ Even though the movement started out as an academic exercise and regularly features in programme units of scholarly organisations like the American Academy of Religion, the scriptural reasoning movement has branched out to schools, prisons, hospitals, religious organisations and citizens' initiatives (Moyaert 2013:64-65). One special example of its application is provided by the activities of the Faith \& Belief Forum Middle East, which uses scriptural reasoning in the healthcare sector in Israel, where "extracts of sacred

\footnotetext{
The call "to always historicise" was popularised by Fredric Jameson (Jameson 1981:ix).

For a description of how scriptural reasoning works, how it is practiced and how it evolved from Jewish textual reasoning, see Moyaert (2013:67-70).
} 
texts are used to explore questions relating to clinical situations" (https://faithbeliefforum.org/programme/middle-east/). The Forum sees its task as educational, as it states on its homepage: "To equip learners with the skills and tools they need to handle and influence relations between different faiths and beliefs" (this latter project focused on the United Kingdom).

By allowing a "harmony of differences" (scriptural reasoners do not strive towards consensus in interpretation of scriptures across the three traditions), scriptural reasoning brings the core identities of the three faith traditions into conversation with each other (Moyaert 2013:65). Scriptural reasoning upholds these core identities because it works with the cultural-linguistic theory of religions (first proposed by George Lindbeck), which assumes the particularist irreducibility of each religious tradition - "[m]eaning is inseparably connected with context, and is intra-textually constituted" (Moyaert 2013:66). Thus, scriptural reasoning sets itself up in opposition to the liberal-pluralist view of interreligious dialogue associated with the names of John Hick (Hick and Knitter 2005; Hick 2005), John Cobb, Alan Race (1993), S. Mark Heim (1995), Jacques Dupuis (2002), and Paul Knitter (2002), whose works are characterised by the assumption of some common soteriology or metaphysical "grounding" shared by all religious traditions. However, for all of its opposition to liberal-pluralist theology of religions, this form of inter-religious dialogue still has as its aim the achievement of some kind of theological convergence: "Finally, whenever Jews, Christians, and Muslims are guests in one another's scriptural traditions, there is more at stake than finding a balance between openness and commitment. Theologically speaking, God is at stake. He is their ultimate orientation in whom they continue to trust (Moyaert 2013:73; my emphasis).

\section{The problem of inter-religious dialogue as practice, and of religious core identities}

The two phrases, practice of inter-religious dialogue and core identities, have been highlighted because they signify the practical interest of inter-religious dialogue in promoting mutual understanding leading to social cohesion ("it is a form of practical wisdom", Moyaert 2013:72), and the fact that, to some extent, each religion is essentialised as a stable and bounded phenomenon. ${ }^{5}$ The latter is flagged because, as

5 In fact, both Jonker and Punt mooted the historically complex formation-history of Christian scriptures in their variety, as well as in the eventual canonical, authorised set of scriptures vested with transcendent sanction as sacred, as an important point of departure in any conversation on the use of Christian scriptures in social argumentation. In a recent paper, "New Testament and Early Christian Studies: Theses towards Theory and Method" (van den Heever 2021), I have expressed this complexity as follows in theses 2 and 3: "Thesis 2: In light of the foregoing, while New Testament Studies is normally conceived as the set of literary objects [the artefactual remains of social interactions], phenomena, and practices that form the foundation for the development and emergence of early Christian traditions, the conjunction of New Testament and Early Christian Studies as understood above, actually inverts the relation such that what is conventionally understood to be denoted by 'New Testament' is a product of early Christianity and not the source for it. Thesis 3: Inverting the relation between New Testament and Early Christian Studies implies the concomitant emphasis on the materiality of the processes whereby early Christianity manifested - material text production, social reproduction processes, social formations, identity-making projects, mythmaking and the inventions of tradition (this includes the material processes of embodiment and cognition, affect and habitus - the affective and rule-conforming interaction with the world; the inscription of sociality on the body). Thus, the discourse of New 
research into so-called lived religion has shown, religious traditions have never existed as anything other than hybrid compositions arising from bricolages of cultural artifacts and ranges of divergent social and cultural performances and embodied, inculcated attitudes. Our notion of religion as a "unitary, organizationally defined, and relatively stable set of collective beliefs and practices" is challenged fundamentally by the phenomenon of "extensive religious blending and with-in group religious heterogeneity" that is the norm rather than exception (McGuire 2008). As Meredith McGuire argues:

Our scholarly theories about religious socialization, conversion, and religiously plural societies have long depicted religion at the level of the individual in terms of commitment to the relatively coherent beliefs and practices of a single, received faith tradition (as identified through an organized religion such as Catholicism or Judaism). What if this picture of the historical norm is completely mistaken? We cannot make any assertions about contemporary hybridity as a new phenomenon without seriously considering whether scholars' earlier depiction of individual religious belonging was no more than an artifact of their definitional and methodological assumptions. Furthermore, when we rethink what is religion, we need also to reconsider our conceptions of religious identity and commitment. Perhaps the borders of religious identity and commitment are as contested, shifting, and malleable as the definitional boundaries of religions. (McGuire 2008:186-87)

McGuire's work is referenced here to caution against facile conceptionalisation of religions-in-dialogue when the internal coherence of a religious tradition is in fact more imaginary than real on the level of lived practice (McGuire reflected on his research into lived religion in the United States of America, but similar research into religious formations in Africa showed comparable states of affairs, see for instance Meyer 1998). If religious expressions and interpretations of sacred scriptures, even if outwardly canonical in character, float in a sea of hybridity, one has to interrogate deeper into the speech-actness of all religious expressions and interpretations and their use-in-context.

\section{The purpose of scholarship on religion: contests about method and theory}

When the practice of inter-religious dialogue is so overtly mooted as the desired aim of a Centre focused on the interpretation of authoritative scriptures (to be fair, not by Jonker and Punt, as the academic "founding figures" for the Centre), it flags an important consideration. At stake is a vision on the purpose of scholarship on religion. ${ }^{6}$ To simplify a much broader and more complex, and at times acrimonious, debate on the

Testament and Early Christian Studies encompasses an investigation of all the concrete operational sites of a given historical social formation's sense of self - its self-understandings, its self-representations, and its self-reinscriptions; and the way in which these manifested in a range of interactional sites, a variety of institutions, conceived spaces, public texts and literary traditions. Viewed like this, New Testament and Early Christian Studies has a natural filial relationship to religious studies, as in itself, an exemplum, as broadly conceived case study of the wider field. As such, New Testament and Early Christian Studies is a natural companion to humanistic studies of society, culture, and politics (as 'the political,' la politique, the sum total of human interactions), and is best seen as a human and social science."

6 See for instance the longer explications of this scholarly conflict of methodology in religious studies in van den Heever (2019; 2020). 
character of religious studies, the battle lines are drawn between what one may label as phenomenological study of religion and what is called redescriptive theorising of religion. The scholarly conflicts centre on attitudes towards the study of religion that see scholarship as a kind of extension of religious values and religious behaviour and therefore inflected by religious commitments. This raises the wider question of the positional relationship that obtains/should obtain between the scholar of religion and the people, their practices, and their traditions, that they study. This question also relates to the way in which the purpose of scholarship and academic work, including the purpose of religious studies as well as the social and moral value of the study of religion, is conceived, or, to rephrase this in Nel's terms, which public's interests should govern the research.

A phenomenological approach implies a sympathetic (perhaps even empathetic) representation of a religious tradition in all its facets, a suspension of suspicion such that what is represented as the insider viewpoint is taken to be the real essence of the religious tradition or practice - the scholar-observer becomes in this view a participantobserver-caretaker. By contrast, redescriptive theorising of religion (see especially the much-referenced foundational formulation of Jonathan Z. Smith in this respect, Smith 2000) proceeds in a fourfold procedure, namely description (as thick a description as possible); comparison (as widely as possible); redescription (in terms of conceptual frames alien to the initial approach to the phenomenon theorised); and rectification of categories (translation of the phenomenon analysed and explained into a container set of categories, the classificatory operation of which causes the phenomenon to be named and identified differently according to the explanatory purposes of the scholar). Such an approach is not immediately affirming of insider-adherents' religious commitments, and there is no conjunction that only insiders may speak to and on behalf of the religious tradition concerned. This kind of theorising is conceptually best at home in the humanities, in which religion is analysed, explained, and theorised as a human phenomenon by means of theories derived from a wide array of human and social sciences (again, the issue of historicisation!). Hence, the explanation of insider concepts like faith or belief, as of religion in its various operations, in such kinds of religious studies as strategies of identity making, of authority-construction, of social formation, of invention of tradition, and so on. The end result need not be deeper understanding of God (or deeper appreciation or commitment to the "house" of the faith tradition that Moyaert speaks of) or the insight-generating excess of meaning funded by inter-religious interpretations of sacred texts. It may have little to do with religious formation at all (which need not be the goal of such study) and instead may lead to critical social and ideology-in-practice analysis, and thus simply aid political commentary on society. ${ }^{7}$

The contours of these clashes of debates manifested clearly in recent roundtable debates in the Journal of the American Academy of Religion (JAAR). The issue of the normativity of scriptural reasoning was addressed with specific reference to recent issues regarding Hindu and Islamic traditions; for instance, JAAR 84, no. 1 (2016) published a "Roundtable on Normativity in Islamic Studies", which addressed issues relating to the

$7 \quad$ Issues in the debate on phenomenology vs. redescriptive theorising are now conveniently reflected and summarised in Arnal, Braun, and McCutcheon (2014). 
role of the Qur'an in Islamic identity formation in contexts of modernity vs. tradition, while JAAR 84, no. 2 (2016) included a "Roundtable in Outrage, Scholarship, and the Law in India", which addressed the now infamous depublishing in India by Oxford University Press of Wendy Doniger's book, The Hindus, on grounds that it misrepresents Hindu religious traditions and constituted an example of Western colonial devaluation of indigenous traditions and an orientalist miscasting of the Other out of disdain for the dignity of the indigenous tradents.

While the two roundtable debates in $J A A R$ did not concern inter-religious dialogue, the theoretical and methodological issues are certainly relevant to the focus and aim of the proposed Centre for the Interpretation of Authoritative Scriptures. It is accepted as a matter of principle that in scriptural reasoning as inter-religious dialogue, the adherents of any of the participating religious traditions do not retain sole ownership and "censorship" over how the scriptures can or should be read and which meanings may be constructed on the basis of the readings - thus "unwanted" or critical interpretations are accepted as occasions for deeper reflection on their own faith. However, given that this kind of inter-religious dialogue functions to promote mutual understanding and greater social cohesion - its practical interest - such dialogue tends to follow in the theoretical footsteps of some of the leading exponents of phenomenological or sympathetic/empathetic study of religion, as for example, the work of Robert Orsi (Orsi 2006; 2012; 2016; see also Griffiths 1998; Omer 2011; Blum 2012; Dunn 2016). This scholarly attitude is expressed strongly in Orsi's introduction to The Cambridge Companion to Religious Studies:

... emphasize that religious theorizing at its best tracks back and forth from lived contexts in the present and the past to the issues and questions of contemporary moment in the academic study of religion, and then back again, allowing each - the empirical and the theoretical - to inform, question, and illuminate the other. (Orsi 2012:11)

Religious theorizing is not done upon men and women, as if they were specimens in the natural sciences, but in relationship to them. It is done alongside them too, as they struggle to understand themselves and their worlds in the available light of their times. (Orsi 2012:9)

In this, he takes up an earlier statement, namely that it is incumbent on scholars of religion to take seriously the real world concerns and investments of religious people and, through scholarship, assist in these life struggles.

It should be clear that matters pertaining to inter-religious dialogue are acutely informed and shaped by how one conceives of the proprium of the study of religion as such; in fact, it is in the end also about the conception and definition of religion. While the reading of religious texts has been at issue in the foregoing discussion on interreligious dialogue, it is time to turn the attention to the theme of reading, that is, to hermeneutics. ${ }^{8}$

As Jonker (2019) sets out the purpose of the Centre-to-be, the intention is to focus on the historical processes of hermeneutics in each of Christianity, Judaism, and Islam, in the formation and the authorisation of their relative 


\section{From hermeneutics to discourse}

The project of investigating the possibility of establishing a Centre for the Interpretation of Authoritative Scripture is formulated explicitly as a hermeneutical enterprise, specifically as a hermeneutic of texts - specific kinds of texts: authoritative scriptures. ${ }^{9}$

Traditionally, hermeneutics has been understood as the study of the interpretation of texts. But note that the phrase, "the study of the interpretation of texts", suggests that hermeneutics is not the same as exegetical methodology, and neither is it the readingexposition of texts (even though theory-informed) for a primary audience; hermeneutics denotes the philosophical or theoretical frameworks for the interpretation of texts and reflection on these frameworks (and again, the issue of historicisation!). From a wealth of examples, I enlist only a few classical "voices" in hermeneutics to illustrate the enduring text-centredness of hermeneutics, namely Paul Ricoeur, Richard Palmer, Anthony Thiselton, and Werner Jeanrond. ${ }^{10}$

I shall adopt the following working definition of hermeneutics: hermeneutics is the theory of the operations of understanding in their relation to the interpretation of texts (Ricoeur 1981:43 my emphasis. See also Ricoeur 1976; 2013).

Hermeneutics is the study of understanding, especially the task of understanding texts. ... hermeneutics achieves its most authentic dimensions when it moves away from being a conglomeration of devices and techniques for text explication and

Scriptures as canons, but also on how these hermeneutical practices inform religiously-based social action by practioners of each of the three traditions. A substantial, and I would say, core part of Jonker's exposition relates to interreligious dialogue, or as he puts it, "the role of hermeneutics in interreligious dialogue" (Jonker 2019: 45--46). Citing with approval Catherine Cornille's exposition on what interreligious hermeneutics does (Cornille and Conway 2010: ix), he highlights - to enumerate only one salient aspect of interreligious hermeneutics - the possibility of "crossing religious boundaries" in the "pursuit of proper understanding of the other." It is at this point that the salience of scriptural reasoning becomes manifest in the project of interreligious hermeneutics (that is, apart from the fact that a number of the original participants in the first workshop on the establishment of the Centre in 2018 also saw it that way). See for instance Marianne Moyart's essay on "Scriptural Reasoning as Interreligious Dialogue" in The Wiley-Blackwell Companion to Inter-Religious Dialogue (Moyart 2013: 6486), as well as the very the substantial section on scriptural reasoning in the volume Interreligious

Hermeneutics in Pluralistic Europe: Between Texts and People (Cheetham, Winkler, Leirvik, and Gruber 2011: 59-128). In fact, the last essay in this section on scriptural reasoning is actually going by the title, "Towards an Interreligious Hermeneutic of Scripture: Problems and Possibilities" (Lambkin 2011: 103-128). Hence, with scriptural reasoning enlisted as one key aspect of interreligious hermeneutics, is with some justification that I gesture towards the intersection of the study and practice of scriptural reasoning with the discourse of interreligious hermeneutics as set out here.

9 In the following, I draw on earlier work on theological hermeneutics, van den Heever (2015:192-197).

10 Over a period of 50 years or so, the careers of Paul Ricoeur, Richard Palmer, Anthony Thiselton, and Werner Jeanrond have greatly set the tone for thinking about hermeneutics and text interpretation in theology and biblical studies. In addition, the oeuvres of Ricoeur, Palmer, and Thiselton have straddled both the fields of theology and philosophy and thus witness to the mutual influencing and co-constitutive character of philosophical, theological, and biblical hermeneutics. See also Porter and Robinson (2011); Porter and Stovell (2012); Jasper (2004); and the classical works by Thiselton on philosophical hermeneutics $(1980 ; 1997 ; 2006)$. I have focused here on text hermeneutics, but the concept of hermeneutics has developed in history to encompass far more than just the interpretation of texts - from the classical sense of the correct interpretation of texts to the interpretive method of the human sciences to a global understanding of human society and human existence. For a short history of the concept of hermeneutics, see Grondin (2009:7-12). 
attempts to see the hermeneutical problem within the horizon of a general account of interpretation itself. Thus it involves two different and interacting focuses of attention: (1) the event of understanding a text, and (2) the more encompassing question of what understanding and interpretation, as such, are. ... Yet human existence as we know it does in fact always involve language, and thus any theory of human interpreting must deal with the phenomenon of language. And of all the variegated symbolic media of expression used by man, none exceeds language in communicative flexibility and power, or in general importance. (Palmer 1969:8-9; my emphasis)

Hermeneutics explores how we read, understand, and handle texts, especially those written in another time or in a context of life different from our own. Biblical hermeneutics investigate more specifically how we read, understand, apply, and respond to biblical texts. (Thiselton 2009:1; my emphasis)

$[\mathrm{H}]$ ermeneutics is concerned with examining the relationship between two realms, the realms of a text or a work of art on the one hand, and the people who wish to understand it on the other. ... we need to reflect ourselves upon how we understand, how much we can understand, and which factors condition our understanding. This reflection is the business of hermeneutics. (Jeanrond 1994:1-2)

To be sure, Anthony Thiselton's definition of hermeneutics is broader than what was suggested in the truncated citation above, since he includes in his definition the fields of literary studies (literary questions about text genres and processes of reading), social studies (about how vested interests, sometimes of class, race, gender, or prior belief, may influence how we read), and theories of communication (Thiselton 2009:1). Nevertheless, and in spite of a broader focus, hermeneutics - particularly the hermeneutics of religious texts - has remained centred on text interpretation.

From the history of hermeneutical thinking, it is clear that hermeneutics is still mostly focused on the interpretation of texts (even if social phenomena or even reality as such can be understood according to the model of the text), or to put it in Ricoeurian terms, textual understanding is the model for all understanding. The text functions as a model and paradigm, and concomitantly, the primacy of textual understanding (or better, understanding through texts) is the foundation for all understanding of religious discourse, especially after the so-called "the linguistic turn" in philosophical hermeneutics, literary and cultural studies since the mid- $20^{\text {th }}$ century. In the case of religious hermeneutics, the self-reflexivity on the process of understanding that intruded into methodological reflection on interpretation at the end of the 18th, beginning of the 19th century, especially in the work of Schleiermacher, implied a broadening of hermeneutics from rules for exegesis into theory of interpretation and from there into metatheoretical reflection on theory formation, on the historicality of interpretation theory, and ultimately to the metatheory of what exactly religion is. ${ }^{11}$ This means that

11 See for instance how John C. Maraldo demonstrates that for all of the wider conceptualisation of hermeneutics to include disclosure of world and practical knowledge as involvement and affective 
the text has become the venue for and nexus of wider questions, such as seeing the text as a cultural artefact and its interpretation as a culturally constitutive action.

John C. Maraldo critiques the text-oriented character of inter-religious dialogue on two main grounds, namely, first, the underlying assumption of the primary textuality of religion and the ramifications this assumption has for conceptualising religion (Maraldo 2010:89-93), and second, for the non-verbal and non-textual possibilities of dialoguing without discourse but through shared practice, "non-textual language" (Maraldo 2010:106-15). ${ }^{12}$ It is especially the first ground that is of significance here. By reducing religion or a religious tradition to its textual expression (sets of scriptures, creeds, doctrines, and so on), a tremendous amount of religious phenomena that co-constitute that particular religious tradition is occluded from view. Not only that, such a textual focus - especially when based on authoritative scriptures, the canonical textualised version of a religious tradition - occludes as well the vast variety of schools of thought, of divergent discourse trajectories existing under the same umbrella, and thus creates the imaginary of a universal tradition, or what Nel calls the grand metanarrative, as if that exists in the singular - for early Christianity (and this would hold for the whole of Christian history) it has become customary to speak of Christianities and Christian identities as much as it has become customary to speak of early Judaisms, and the same would hold for Islam (and again we are in the complex territory of lived religion as McGuire explained above). ${ }^{13}$ And thus, as Maraldo points out, in more recent theories of religion, polythetic definitions of religion have emerged that show that a range of features constitute what can be called a religious tradition.

Recourse is in this regard often taken to the polythetic definition of religion by Bruce Lincoln, the well-known historian of religion from Chicago: A religion is a discourse that has authority and is regarded as embodying truth (ways of talking about divinities and ultimate truths, revelations and revelatory scriptures, ethical precepts that are to be upheld, ancestral traditions). It is a set of practices, ethical and ritual practices motivated by revelatory discourse and tradition. It is a community whose members construct their identity with reference to a religious discourse and its attendant practices. And it is an institution that regulates religious discourse, practices, and community, reproducing them over time and modifying them as necessary, while asserting their eternal validity and transcendent value (Lincoln 2003:5-7). To call this a polythetic definition means

interaction with the world in which we live (esp. in Heidegger, but also Gadamer and Ricoeur), in the end, the conceptualisation of hermeneutics bends back to the issue of the interpretation of texts, for understanding of the world and acting in that world comes to understanding in language - as text (Maraldo 2010). See the famous statement of Hans-Georg Gadamer in Wahrheit und Methode, "Sein das verstanden werden kann, ist Sprache" = "Being that can be understood is language" (Gadamer 2004: 470).

12 I will not devote further discussion to the shared practice example Maraldo discusses, as my interest lies elsewhere, with the definition of religion at stake. It will suffice to point out that he mentions shared meditational practices between European Benedictine and Japanese Zen monks.

13 David Frankfurter has shown, with respect to the Christianisation of Late Ancient Egypt, how Christianity was by nature a hybrid "beast": As Frankfurter argued in Religion in Roman Egypt and newly in Christianizing Egypt, "conversion" is an inappropriate concept to describe and explain the re- and inculturation processes that play out when new symbolic discourses are negotiated when newly introduced symbolizations interweave with long-established cultural practices, folk customs, and identities (Frankfurter 2000; 2017). 
simply that these features will not apply or be operationalised in the same manner or to the same degree in every kind of social formation we might label a religion. But from this definition, one can easily understand why, in redescriptive theorising of religion, "religion/religious tradition" dissolves into historicised human operations of discourse, mythmaking, identity construction and -maintenance, social formation, cultural performance, and so on. ${ }^{14}$ To pursue the point further, in his famous "Theses on Method", Lincoln stresses the matter in pointed fashion as follows:

2.... Religion, I submit, is that discourse whose defining characteristic is its desire to speak of things eternal and transcendent with an authority equally transcendent and eternal. History, in the sharpest possible contrast, is that discourse which speaks of things temporal and terrestrial in a human and fallible voice, while staking its claim to authority on rigorous critical practice.

3. History of religions is thus a discourse that resists and reverses the orientation of that discourse with which it concerns itself. To practice history of religions in a fashion consistent with the discipline's claim of title is to insist on discussing the temporal, contextual, situated, interested, human, and material dimensions of those discourses, practices, and institutions that characteristically represent themselves as eternal, transcendent, spiritual, and divine.

4. The same destabilizing and irreverent questions one might ask of any speech act ought be posed of religious discourse. The first of these is "Who speaks here?", i.e., what person, group, or institution is responsible for a text, whatever its putative or apparent author. Beyond that, "To what audience? In what immediate and broader context? Through what system of mediations? With what interests?" And further, "Of what would the speaker(s) persuade the audience? What are the consequences if this project of persuasion should happen to succeed? Who wins what, and how much? Who, conversely, loses?" (Lincoln 2005:8; my emphasis) ${ }^{15}$

Note the discordant claims here: the claim that religion is a discourse concerned with transcendent value (whether you call it truth, universal truth, access to divinity, etc.), and the claim that the study of the foregoing is a fully human historical operation that is fully invested in conceptualising religious discourse in its speech-actness and socio-cultural and ideological performativity, where this performativity is conceived of as the occasion for the exercise of inducements and power-effects. Once one has made the move to this point in hermeneutics of religion, it should be clear that what one is speaking of here is religion as a species of discourse production. I have, over the years, developed this definition of discourse (following Michel Foucault and others but broadening it to focus not so much on what is said but on the broader operations of signification):

14 In studies of Christian origins, this has become standard terminology through which to theorise early Christian formations (see, e.g., Miller 1996; Cameron and Miller 2004; Martin 2004).

15 A similar point is made in his essay, "How to Read a Religious Text" (Lincoln 2012: 5-15) 
"Discourse" is the surface manifestation of the processes underlying it and which give rise to it; as the sum total of regulated utterances and corpora of significations that appear as a specific discourse. "Discourse" is the encompassing set of representations of what is/can be known (however broadly conceived; basically "set of representations" denotes a domain of knowledge, a domain of what we cognise as reality, more specifically, a domain of disciplinary knowledge; but it includes all manner of signifying practices - speech, gestures, texts, performances, signs, spaces, material objects, environments as arranged space, the rhythms of life as hidden persuasions), in conjunction with the originary matrix that gave rise to that set of representations (which implies as well its historical genealogy). "Discourse" encodes the social interests encompassed/encapsulated in and giving shape to these sets of representations. As well, "discourse" cannot be conceived apart from the logic governing the interrelations between the constituent factors or aspects of the relevant set of representations, and encompasses the institutionalisation of such "domained" representations in canons of tradition, schools of thought, habitus as habituated action, social formations, cultural and socio-political-economic conventions, that is, as discursive formations. "Discourse" includes the social location or the context for the discourse, and the social, cultural, and ideological work the discourse performs, in addition to the effects of the institutionalisation of that discourse in conventions of scholarship.

While "discourse" itself appears as an abstract concept, it is actually a taxon with which to investigate all the concrete operational sites of a given historical society's sense of self - its self-understandings, its self-representations, and its selfreinscriptions; the way in which these manifest in social and political institutions, the monumentalised environment, public texts and literary traditions - and the way power (understood as the operation of "force relations" - Foucault's term, but for which I prefer the term "inducements" to signify "that which causes things to happen") is dispersed through all interactional sites of engagement or withdrawal. Instead of viewing power/force relations as the concrete instantiation of power exercised by an individual or a repressive institution, Foucault considers the more pervasive and insidious mechanisms by which power (or, the operations of inducement) affects the lives of individuals intimately, somatised in shaping bodies, bodily actions, attitudes and dispositions, discourses, cognition of reality and everyday lives. Discourse understood like this has as its complement embodied discipline as habitus, as embodied rule conformance - we live in accordance with our "knowledge-world." (van den Heever 2019:26-27)

If one follows the move from hermeneutics to inter-religious hermeneutics to discourse, then it should be clear that what is at stake in such a study is actually a study of how subsections or factions of society operate in reproducing themselves. Interreligious hermeneutics then becomes a study of social formations and social rhetorics.

\section{Comparative hermeneutics of religion}


A last consideration has to be made, and this one concerns the implications of a comparative hermeneutic of religion. In the little-known volume on comparative hermeneutics of Christianity and Buddhism, The Cardinal Meaning (Pye and Morgan 1973), ${ }^{16}$ it is shown how in a range of historical interpretations of Christianity and Buddhism various logics govern the conceptualisation of each religion. A threefold typology thus emerges across the various historical interpretations of the two religions: If one elects to understand a religious tradition as an archive of meaning, then the question arises regarding what, precisely, the archive is that is preserved and transmitted. This is where the question of the coherence and identity of religious traditions becomes such a strident issue. This is also where the threefold typology becomes an issue: Is the identity of a tradition given by the earliest layer of it? Or a canonical version of it? Or should one accept that a religious tradition is everything produced in its name over the course of its history (and thus, there are really no essential boundaries to what a tradition can encompass)? (And the perceptive reader will realise full well that here one is again in the domain of questions regarding the nature and character of religious metanarratives that Nel treated in his essay.) What the volume The Cardinal Meaning demonstrates is that the issue of comparative hermeneutics reaches far wider than just the practice of hermeneutics; it also implies a reconstruction of the history of (a particular) religion and a theory of religion.

If one takes the view of Jonker as expressed in his essay, namely that the project is historical in character and that the historical formation of religious traditions and canons form part of what is investigated, then the last option above should be the operative one. But that raises serious questions about what is compared to what. Certainly, in any interreligious comparative hermeneutic, one will have to reckon with fluid and unstable traditions and religious identities. In fact, one might ask if the only thing achieved in such comparative hermeneutics is not just individuals reaching compacts towards social cohesion and not religions.

\section{Conclusion}

Comparative hermeneutics is more than (just) an analysis of the practices of interpretation - the underlying assumptions and philosophy, the rules for interpretation, etc. - in each of the three main monotheistic religious traditions in South Africa, as these practices shape each tradition's impact on society. Comparative hermeneutics is also more than (just) reflection on how each of these traditions operationalises its interpretation of authoritative scriptures in the same social space (and thus, by extension, also in interplay with each other). A comparative hermeneutic will also have to raise the question regarding whether or not there is something comparable to the three monotheistic religious communities and their traditions and practices. Another way of putting this last question is as follows: Are these three monotheistic communities Christianity, Islam, and Judaism - in-themselves-subsisting freestanding, sui generis

16 I call this a little-known volume because I have not been able to trace much reference to it in scholarly literature. This is great pity, for the collection of essays raises pertinent questions regarding the practice of comparative religion and the implications this has for conceptualising any particular religious tradition. 
phenomena, or is there a perspective on them that will allow for standing outside the insider-outsider divide to see and theorise the operations of discourse-making that are similar to all three?

The answer developed in this essay is to point to conceiving of religions or religious traditions as species of discourse production, as kinds of human social speech acts that are best studied within the framework of redescriptive theories of religion. It is exactly in the domain of redescriptive theorising where historicising concepts like mythmaking, social formation, identity construction, invention of tradition, and discourse production anchor the project of a Centre for the Interpretation of Authoritative Scriptures in the real, concrete world where humans go about constructing their lifeworld and devise ways of living together with others in society.

\section{BIBLIOGRAPHY}

Arnal, William E., Braun, Willi, and McCutcheon, Russell T. (eds.), 2014. Failure and nerve in the academic study of religion. Sheffield; Bristol, CT: Equinox.

Blum, Jason N. 2012. Retrieving phenomenology of religion as a method for religious studies, Journal of the American Academy of Religion 80(4):1025-48. https://doi.org/10.1093/jaarel/lfs080.

Cameron, Ron, and Miller, Merrill P. (eds.), 2004. Redescribing Christian origins. SBL Symposium Series 28. Atlanta, Ga.: Society of Biblical Literature.

Cornille, Catherine, and Conway, Christopher (eds.), 2010. Interreligious hermeneutics. Eugene, OR: Cascade Books.

Dunn, Mary. 2016. What really happened: Radical empiricism and the historian of religion, Journal of the American Academy of Religion 84(4):881-902. https://doi.org/10.1093/jaarel/lfw011.

Dupuis, Jacques. 2002. Christianity and the religions: From confrontation to dialogue. Maryknoll, N.Y.: Orbis Books.

Engler, Steven, and Grieve, Gregory P. (eds.), 2005. Historicizing "tradition” in the study of religion. Religion and Society 43. Berlin; New York, N.Y.: de Gruyter.

Frankfurter, David. 2000. Religion in Roman Egypt: Assimilation and resistance. Princeton, N.J.; Chichester: Princeton University Press.

- 2017. Christianizing Egypt: Syncretism and local worlds in Late Antiquity. Martin Classical Lectures. Princeton, NJ; Woodstock: Princeton University Press.

Gadamer, Hans-Georg. 2004. Truth and method. Translated by Weinsheimer, Joel, and Marshall, Donald G. 2nd rev. ed. London; New York, NY: Continuum.

Grieve, Gregory P., and Weiss, Richard. 2005. Illuminating the half-life of tradition: Legitimation, agency, and counter-hegemonies. In Engler, Steven, and Grieve, Gregorgy P. (eds), Historicizing "tradition" in the study of religion. Religion and Society 43. Berlin; New York, N.Y.: de Gruyter,1-15.

Griffiths, Paul J. 1998. Response: Some confusions about critical intelligence: A response to Russell T. McCutcheon, Journal of the American Academy of Religion 66(4):893-96. https://doi.org/10.1093/jaarel/66.4.893. 
Grondin, Jean. 2009. Hermeneutik. Translated by Blech, Ulrike. UTB 3202. Göttingen: Vandenhoeck \& Ruprecht.

Heim, S. Mark. 1995. Salvations: Truth and difference in religion. Faith Meets Faith Series. Maryknoll, NY: Orbis Books.

Hick, John. 2005. An interpretation of religion: Human responses to the transcendent, Second Edition. 2nd rev. ed. New Haven, CT: Yale University Press.

Hick, John H., and Knitter, Paul F. (eds.), 2005. The myth of Christian uniqueness:

Toward a pluralistic tTheology of religions. Eugene, OR: Wipf \& Stock.

Jameson, Fredric. 1981. The political unconscious: Narrative as a socially symbolic act.

Ithaca, NY: Cornell University Press.

Jasper, David. 2004. A short introduction to hermeneutics. Louisville, KY: Westminster John Knox Press.

Jeanrond, Werner G. 1994. Theological hermeneutics: Development and significance. Repr. ed. London: SCM Press.

Jonker, Louis. 2019. Establishing a Centre for the Interpretation of Authoritative Scriptures (CIAS): Why focus on hermeneutics?, Religion and Theology 26(12):41-51. https://doi.org/10.1163/15743012-02601005.

Knitter, Paul F. 2002. Introducing theologies of religions. Maryknoll, N.Y.: Orbis Books.

Lambkin, Magdalen. 2011. Towards an interreligious hermeneutic of Scripture: Problems and possibilities. In Cheetham, David, Winkler, Ulrich, Oddbjørn, Leivrik, and Gruber, Judith (eds), Interreligious hermeneutics in pluralistic Europe: Between texts and people. Currents of encounter: Studies on the contact between Christianity and other religions, beliefs, and cultures, 40. Amsterdam; New York, NY: Rodopi, 103-128.

Lewis, James R, and Hammer, Olav (eds.), 2007. The Invention of sacred tradition.

Cambridge; New York, NY: Cambridge University Press.

Lincoln, Bruce. 2003. Holy terrors: Thinking about religion after September 11.

Chicago, IL; London: University of Chicago Press.

. 2005. Theses on Method, Method \& Theory in the Study of Religion 17(1):810.

. 2012. Gods and demons, priests and scholars. Critical explorations in the history of religions. Chicago, IL/London: University of Chicago Press.

Maraldo, John C. 2010. A call for an alternative understanding of interreligious hermeneutics. In Cornille, Catherine and Conway, Christopher (eds), Interreligious hermeneutics. Interreligious Dialogue Series 2. Eugene, OR: Cascade Books, 89115.

Martin, Luther H. 2004. Redescribing Christian origins: Historiography or exegesis? In Cameron, Ron and Miller, Merrill, P. (eds.), Redescribing Christian origins. SBL Symposium Series 28. Atlanta: Society of Biblical Literature, 475-81.

McGuire, Meredith B. 2008. Lived religion: Faith and practice in everyday life. Oxford; New York, NY: Oxford University Press.

Meyer, Birgit. 1998. 'Make a complete break with the past.' Memory and post-colonial modernity in Ghanaian Pentecostal discourse, Journal of Religion in Africa 28(3):316-49. https://doi.org/doi.org/10.2307/1581573. 
Miller, Merrill P. 1996. Ancient ayths and modern theories of Christian origins: A discussion, Method \& Theory in the Study of Religion 8(3):229 - 230. http://dx.doi.org/10.1163/157006896X00332.

Moyaert, Marianne. 2013. Scriptural reasoning as inter-religious dialogue. In Cornille, Catherine (ed.), The Wiley-Blackwell companion to inter-religious dialogue. WileyBlackwell Companions to Religion. Malden, MA; Oxford: Wiley-Blackwell, 6486.

Nel, Marius J. 2019. The relationship between Christian metanarratives and authoritative scriptures in South African society, Religion and Theology 26(1-2):72-83. https://doi.org/10.1163/15743012-02601002.

Omer, Atalia. 2011. Can a critic be a caretaker too? Religion, conflict, and conflict transformation, Journal of the American Academy of Religion 79(2):459-96. https://doi.org/DOI: 10.2307/23020434.

Orsi, Robert A. 2006. Between Heaven and earth: The religious worlds people make and the scholars who study them. Princeton, NJ: Princeton University Press.

, ed. 2012. The Cambridge companion to religious studies. Cambridge; New York, NY: Cambridge University Press.

- 2016. History and presence. Cambridge, MA; London: Belknap Press.

Palmer, Richard E. 1969. Hermeneutics. interpretation theory in Schleiermacher, Dilthey, Heidegger, and Gadamer. Northwestern University Studies in Phenomenology and Existential Philosophy. Evanston, IL: Northwestern University Press.

Porter, Stanley E., and Robinson, Jason C. 2011. Hermeneutics: An introduction to interpretive theory. Grand Rapids, MI; Cambridge: Eerdmans.

Porter, Stanley E., and Stovell, Beth M. (eds.), 2012. Biblical hermeneutics: Five views. Downers Grove, IL: InterVarsity Press.

Punt, Jeremy. 2019. What are authoritative scriptures?, Religion and Theology 26(12):52-71. https://doi.org/10.1163/15743012-02601004.

Pye, Michael, and Morgan, Robert (eds.), 1973. The cardinal meaning: Essays in comparative hermeneutics: Buddhism and Christianity. Religion and Reason 6. Berlin; New York, N.Y.: de Gruyter Mouton.

Race, Alan. 1993. Christians and religious pluralism: Patterns in the Christian theology of religions. 2nd ed. London: SCM Press.

Ricoeur, Paul. 1976. Interpretation theory: Discourse and the surplus of meaning. Fort Worth, TX: Texas Christian University Press. . 1981. Hermeneutics and the Human Sciences: Essays on Language, Action, and Interpretation. Edited by John B. Thompson. Cambridge; New York, NY: Cambridge University Press.

- 2013. Hermeneutics: Writings and lectures. Cambridge; Malden, MA: Polity. Smith, Jonathan Z. 2000. Bible and religion, Bulletin of the Council of Societies for the Study of Religion 29(4):87-93.

Thiselton, Anthony C. 1980. The two horizons: New Testament hermeneutics and philosophical description. Grand Rapids, MA: Eerdmans. . 1997. New horizons in hermeneutics. The theory and practice of transforming biblical reading. Rev. ed. Grand Rapids, MI: Zondervan. 
. 2006. Thiselton on hermeneutics. Ashgate contemporary thinkers on religion: collected works. Aldershot; Burlington, VT: Ashgate.

. 2009. Hermeneutics: An introduction. Grand Rapids, MI.; Cambridge: Eerdmans.

Van den Heever, Gerhard. 2015. What do you read when you read a religious text? Open question and theses towards an anti-hermeneutic, Religion \& Theology 22 (34):187-218. https://doi.org/10.1163/15743012-02203011.

. 2019. Introduction. Reflections on the ampersand: A manifesto of sorts, etc. etc., Religion \& Theology 26(1-2):1-39. https://doi.org/10.1163/1574301202601008.

- 2020. Beyond the Insider: Outsider Perspective-The Study of Religion as a Study of Discourse Construction. In Hensold, Julian, Kynes, Jordan A., Öhlmann, Phillip, Rau, Vanessa, Schinagl, Rosa Coco, and Adela Taleb (eds.), Religion in Motion. Rethinking Religion, Knowledge and Discourse in a Globalizing World. Basel: Springer Nature Switzerland, 141-164.

. 2021. New Testament and Early Christian Studies: Theses on Theory and Method. Journal of Early Christian History 10(1):1-3.

https://doi.org/10.1080/2222582X.2020.1848443. 